Rafał RIEDEL

DOI : 10.14746/pp.2017.22.3.1

University of Opole

\title{
Economic Nationalism and Populism - Intertwining Relations
}

\begin{abstract}
The objective of the paper is to analyse two very closely related categories, economic nationalism and economic populism. They intertwine both in the lived politics on the ground and in intellectual debates. Despite a rich interdisciplinary discourse, scholars interested in economic nationalism and economic populism still disagree not only how to explain them, but more fundamentally - about what they are and what their relation is. This paper answers this deficit by addressing the question of the intertwining connections between economic nationalism and populism. In the first instance it reconstructs the basic definitions of economic nationalism - its constitutive elements, its historicity and periodization as well as its main categorisations. The next section focuses on economic populism, it starts with reconstructing the general definitions of populism and then consequently emphasises its economic dimension. In the conclusive part, as well as in throughout the argumentation of whole text, the author highlights the relations between economic nationalism and populism, their overlapping components and elements that they do not share. The origins of populism (as a movement) were economic in nature. Economic populism (as an empty-hearted ideology) is intertwined with nationalism in many of its contemporary (re)incarnations. Both economic nationalism and populism are increasingly important due to their raising political popularity and they require a closer look and scholarly attention.
\end{abstract}

Key words: economic nationalism, economic populism, contents, relations, intertwining

\section{Introduction}

$\mathbf{N}$ ationalism and populism do not enjoy the best reputation in general. In the common language and every-day usage they both carry a dose of pejorative connotations. But subjective position towards the object of research may not act as an excuse for watering down the scientific conceptualizations and their analytical operationalizations. Therefore this study offers a closer look at the phenomena of economic nationalism and populism trying to identify their core features as well as the overlapping and distinguishing elements.

Economic populism has become almost a by-word to imply irresponsible economic decisions and policies or political pandering (demagoguery and populism are in this sense used almost interchangeably). In political rhetoric battles, many commentators try to pin it on anyone deviating from a certain economic orthodoxy ("misleading the people with false promises"). Anyone expressing fear from globalization or modernization can be labeled a populist (Mueller, 2015). Both economic populism and nationalism are based on the political-economic ideology postulating the rights of the real people ("the nation", "the locals", "the domestic capital" etc.). It became politically productive in the context of the crisis - anti-market populism has been given a boost by the economic recession. But an irresponsible, populist economic program, when implemented, may bring high vulnerability that makes further destabilisation possible. When the external shock comes, it is the earlier unsustainable policies that makes 
things worse. The victims usually are the common people, to which both populists and nationalists appeal.

The theories predict that the appeal of illiberalism (to which both populism and nationalism refer to) increases together with the worsening of the economy and declines when the economy improves (Kubik, 2012). The economic crisis (2007-2013) intensified economic grievances and stimulated the populist and nationalist rhetoric and action. Prejudice and discriminatory attitudes towards out-groups spread across the European continent and in many places became the dominant narrative of mainstream politics. No matter if it is the class-based notion of economic populism or partisan elections-driven economic nationalism, there is more acceptance for both. The xenophobic and ethnonationalist frames are employed to serve to construct meanings about the "other". The combination of nativism and comprehensive protectionism seeks to exploit the anxieties and feelings of insecurity originating from the socio-economic determinants, like globalisation, transformation or crisis (Kluknavska, 2014). The backward-looking ideas of contemporary populists go back to the economic origins of agrarian populism promoting the saving of small farm agriculture as the backbone of the economy and society. The claim that one of the first modern appearance of populism were the Russian Narodniki movement supports the thesis of the close relationship between nativism and populism. This short-lived movement of intellectuals articulated the idea that the true wisdom resides with the common people. The heartland population (Taggart, 2004) is the main point of reference for both populists and the nationalists. It affects politics both on the right-wing and the left-wing of the wide political spectrum. Mainstream politicians are increasingly adopting localism (Wills, 2015) and "our way of life" as a framework for policy and politics making.

The populism on the ground (as a thin-centred ideology) needs to be supplemented with additional values and beliefs. By doing this it cohabits with other more comprehensive ideologies, depending on the context. This is why populism's power (and danger at the same time) lies in its chameleonic nature, which is adapting its face according to the context and connecting itself to other political ideas or ideologies. As a consequence it is difficult to find one political arena free from populist actors, tactics or statements. We can identify agrarian populism, nationalistic populism, neoliberal populism, radical left-wing populism and so on. Very often the empty hearted or thin centered ideology of populism is filled with the nationalist contact and this intriguing cohabitation is the source of motivation for scholarly inquiery.

This paper proceeds as follows: the first section addresses the question of economic nationalism - its constitutive elements, its historicity and periodization as well as its main categorisations. The next section focuses on economic populism. It starts with reconstructing the general definitions of populism and then consequently emphasises its economic dimension. In the conclusive part, as well as in throughout the argumentation of whole text, the author highlights the relations between economic nationalism and populism, their overlapping components and elements that they do not share. The origins of populism (as a movement) were economic in nature. Economic populism (as an emptyhearted ideology) is intertwined with nationalism in many of its contemporary (re)incarnations. Both economic nationalism and populism are increasingly important due to their raising political popularity and they require a closer look and scholarly attention. 


\section{Economic nationalism - contents, periodization, categorizations}

One of the most powerful ideologies of modern times, that is nationalism, has its very salient economic dimension, which is relatively poorly understood and explained in academic terms. It has to do with the fact that nationalism as a political slogan carries a strong - very often pejoratively associated - connotation. Used as an epithet in public discourse, it usually means, protective, maybe even isolationist, aggressively oriented towards others policies, actions or rhetoric. Many scholars still employ the term almost synonymously with mercantilism or protectionism (Shulman, 2000). But economic nationalism, as a scholarly concept, carries much more explanatory potential and should be dedicated organized, systematic and scientific reflection which challenges some of the conventional wisdoms.

Nationalism itself is a state of mind in which the individual identifies himself with the "we-group" to which he is loyal. Within the "we-group" prejudice and discrimination is generated by the real or hypothetical threat coming from some other "out-group". To justify the prejudice and discrimination, negative stereotypes of the "out-group" are developed (usually based on the perceived fear about the physical, social or economic health of the "in-group"). There is a number of social psychological works analyzing the link between authoritarian personality and the "in-group" - "out-group" orientations. They inform us that nationalism (including economic one) are highly and positively correlated with ethnocentrism, authoritarianism and conservatism as well as negatively correlated with internationalism.

Economic nationalism needs to be positioned very close to economic populism since nationalism is one of the ideologies that overlap and complement the thin-centered ideology of populism. It refers to the people understood as a nation as well as its economic interest and security. Especially together with the growing salience of economic security, the economic nationalism becomes and increasing component of nationalistic sentiment.

It can be most simply understood as discrimination in favor of one's own nation. It is implemented in many various forms and measures, including policy implementation, protectionism, subsidizing domestic producers and service providers, regulatory burdens, export dumping, countervailing duties and many others. Economic nationalism may also take some more soft forms, like for example favoring local products and services by consumers' choices.

Economic nationalism stands in contrast to the long-standing general trends of globalized (and ever globalizing) economy. It creates barriers for economic liberalism and liberalization, being a paradox in an increasingly borderless world (in the context of the benefits stemming from it) (Baughn, Yaprak, 1996). Sam Pryke (2012) defines it as a set of practices to create, bolster and protect national economies in the context of world markets, which resonates very well with the XXI century reality of the global economy. Even after the economic crisis 2007-2013, there has been no observed return of economic nationalism as in a generalised rise in protective policies. However, together with the growing instability and nationalist rhetoric in general, the risk of the economic nationalism resurgence is increasing.

The advent of economic globalization and the perceived threat to national identities encourage the protection of local cultures, which takes the form of nationalism, tribal- 
ism or nativism. Some of the most intensive outbursts of nationalism may be observed in nations which have felt themselves exploited or have believed that the benefits of globalization are passing them. The feeling of unjust and instability is a fertile ground for religion, traditional culture and ethnicity to step in. Secularism found itself in defense and has been targeted as an enemy. The same some with other alien religions and ethnicities that are supposed to clash with ours. Self-victimization and messianism accompany very often the above-mentioned phenomena and they all support the development of nationalisms in various forms, including the economic nationalism.

Defining economic nationalism as a promotion of given nation's autonomy, unity and interests, allows to argue that nationalists potentially may have strong motivations both for and against close economic ties with foreign economies. Depending on the international position of a given national economy, nationalists may need to make trade-offs and compromises in order to optimize their strategy and tactics. The nationalist calculus of independence and interdependence or integration does not always bring about protectionist outcomes. It is because of the interdependency of the economies and complexity of global economy as such that makes it impossible to separate by nationality. In Ukraine - nationalists promote closer ties with EU as a counterbalance to the alternative - the Russian domination. In Canada, free trade is supported as a way of reducing the central state's power (Shulman, 2000). But generally it was defined in opposition to economic liberalism and therefore it means predominantly everything that the economic liberals do not like. This is also a reaction to the fact that economic nationalists built their position on criticizing liberal economic policies (free trade imperialism of the wealthy and powerful). In scholarly literature the phrase started to be used by international relations experts (increasingly widely in in 1970s) as an economic variant of the ideology of realism (Helleiner, 2002).

Economic nationalism so far has been regarded rather as a set of attitudes then a coherent theory, however some scholars argue (Nakano, 2004) that bringing the concept of nation into political economy may result into systematic theory of economic nationalism. Here however we are much more interested into the ideology of economic nationalism. It usually consists of protectionist and aggressive state intervention (Berend, 2000).

Political and economic nationalism are intertwined and this relation is dynamic. Economic nationalism was associated with different kinds of ideas and policies in various times and places. Economic nationalism, like nationalism in general, was linked to the development of the nation state, in this particular case - the ability to establish and run a national economy. Due to the fact that we live in a global economy, the nationalist "age of glory" fades away. So do the state-centric ways of defining economic nationalism as if it was supposed to be an idea (or maybe even ideology) according to which economic activities should be subordinate to the goal of the state building (Gilpin, 1987) and serve its interests. Many scholars (Helleiner, 2002) would suggest re-reading of Friedrich List, as the most classical and so-far prominent economic nationalist. In his most influential book The National System of Political Economy, written in 1844, he promotes infant industry protection (which does not place him far away from the other classics of economics, like Adam Smith, David Ricardo o John Stuart Mill) but, what is vitally important, he criticizes liberals that they put individuals in the center of their ideology, whereas in his opinion it should be the nation. His general concept of economics as a discipline was 
that it should be "[...] a science which limits its teaching to the inquiry of how a given nation can obtain prosperity, civilization and power." (List, 1904, p. 97).

Since the collapse of economic Marxism, it was regarded that the economic liberalism is the only legitimate successor. It soon appeared that other strands of economic ideologies became salient and filled the vacuum, one of them being economic nationalism. Parallel to redefining their stands in the context of globalization and multiculturalism, the nation-states have to adopt their economic perspective and approaches.

Economic nationalism remains an important factor that mobilizes population around a state-sponsored economic vision. It can be economic nationalism of mineral resources, or protecting the local population from "free trade imperialism" of an economically powerful neighbor, or persuading the citizens to keep their own currency in order to preserve the rest of national sovereignty, or any other political-economic argument against the economic parasites of the true people. It may be associated with economic patriotism of those buying local products and services instead of the global brands. Economic nationalism has many faces. No question, there are elements of nationalism and economic nationalism in all countries and economies (Isaacs-Martin, 2011).

\section{The origins of populism were economic}

Despite a rich interdisciplinary discourse, students of populism still disagree not only how to explain it but more fundamentally - about what it is. ${ }^{1}$ We seem to be witnessing a conceptual cacophony. The most common ways of understanding populism contain of its minimum components: "the good people" that is endangered by "the evil others". Such an alignment runs crosswise of established party lines. Such a definition of populism correlates with the general every day usage of this word whenever, usually for journalist purposes, we refer to a person, party, action or decision that makes claims by appealing to ordinary, non-elite people. In public discourse it is often used as a pejorative epithet implying that the accused is corrupt, cynical, opportunistic or even undemocratic. It lacks the necessary precision adequate for scientific inquiry that would allow to capture the features of this flexible way of animating politics.

Modern populism is regarded to exist already in nineteenth century (agrarian populism in USA in the form of People's Party or Russian narodnichestvo). The origins of populism itself were economic in nature - it was the political ideology of agrarian radicalism and its concept of "cooperative society" that proposed more "fair" economic redistribution of wealth in XIX America. By attacking inequalities in income, assets, and consequently influence they drew the first economic populist program of the "authentic Americans" (nativism). The other was at that time the enemies of the "ordinary people": the bankers (including funds, investors, and so on) and industrialists (including corporations, stock companies and so on). The non-aristocratic character of the American elite was not a problem for the populists as they quickly invented terms like "money aristocracy" which holds effective until today. It is surprising how the early industrialist era slogans are valid at the beginning of the XXI century: national healthcare system,

${ }^{1}$ The etymology of the term goes back to the ancient Rome where populares, used to be the term defining the politicians looking for public support. 
eight-hour working time, obligatory unemployment and health insurance. One of the first analytical works on populism appeared in 1929 in "The American Economic Review" where John D. Black published his article on The McNary-Haugen Movement. He discussed political and economic aspects of the relations between the agricultural sector and commerce and industry. This field of analysis correlates very well with the populist ideology from the agrarian revolt in USA in 1890s and the accompanying concept of the two nations: the nation of the producers (the exploited) and the nation of the well-to-do elites. This distinction gave birth to the political cleavage present in populist politics that is the confrontational relation between the authentic people and the parasitical elite.

The most recognised and cited contemporary researcher of populism, Cas Mudde, defines it as a thin-centred ${ }^{2}$ ideology that focuses on the antagonism between people and elites against the backdrop of popular sovereignty. Such conceptualisation has become the dominant position in the literature. It considers society to be ultimately divided into two homogenous and antagonistic groups "the pure people" and "the corrupt elite" (Mudde, 2004, p. 543) and politics is supposed to be an expression of the general will of "the pure people". This positions populism in opposition to elitism and pluralism. In populist politics there are less spaces left for minorities and they are often presented as traitors to the real will of the nation or even marionettes of foreign powers. There are however raising concerns about assigning populism's genus to ideology. The controversy on populism as an ideology stems from the fact that it falls short of the status of clear ideology. It went, as a concept, through a dynamic evolution, serving for various associations with fiscal irresponsibility (there is no uncontested clear line between responsibility and irresponsibility), neo-liberal extremism or xenophobic stances. It lacks a stable program (empty hearted ideology). As a result there is little agreement on how to conceptualise populism and it is marked by a high degree of contestability. The category of populism has been so widely used that it lost its analytical value and explanatory potential.

Some scholars claim that populism is best seen as strategy in which the government power is exercised based on direct, unmediated and very often not institutionalised support from a large number of mostly unorganised followers. Populism as a political strategy employs rhetoric which is the appeal to emotions, very often used cynically and opportunistically. As such, populism is relatively close to demagoguery that tends to promise (or overpromise) people whatever they want to hear. Some other authors see populism as a type of organisation or institution - in the wide sociological understanding of this work. A party can be populist, a movement or unified bock or movement. Undoubtedly Mudde's works had a significant impact in advancing scientific analysis of populist politics. However there is a growing scepticism against this perspective claiming that the ideological connotations of populism are ill-centered or misclassifications. Instead, proponents of frame theory, contend that the frame analysis reveals a strong fit between discursive elements and cognitive features of populism. Therefore 'discourse' is believed to be better suited to characterize the conceptual genus of populism. And pop-

2 "Thin" due to the fact that its particular ideas are of limited scope, complexity and ambition, it is not a complete ideology in opposition to full ideologies, like: nationalism, socialism or liberalism. Michael Freeden explained a thin-centered ideology that is arbitrary in serving itself from wider ideational contexts, it flexibly removes or replaces some concepts, it lacks internal integrity and coherence (Freeden, 1998). 
ulism itself is defined from this perspective as a discourse, invoking the supremacy of popular sovereignty to claim that corrupt elites are defrauding the People of their rightful political authority (anti-elite discourse in the name of the sovereign people) (Aslanidis, 2015). This approach considers populism as anti-status quo discourse by symbolically dividing society between "the people" and "the other" (Moffit, Tormey, 2014), validating the "them-and-us" mentality. When populists claim to speak in the name of the people, they attempt to bring "people" into being and it gives them unlimited freedom in manipulating who the "the people" are and what characteristics they have. The same with "the other" - its creation, features and performance is highly subjective and can be easily adaptable to the current needs of the populist politics. The relation between the imagined "people" (the nation, the poor, the natives, the "let down", the "badly governed", the "left alone" etc.) and equally imagined "other" (migrants, refugees, traitors, the experts, the establishment, the technocrats, the system, etc.) reveal major components of the specific populist Weltanschaungen.

For Jansen (2011, p. 82) a political project is populist when it is a sustained, largescale political project that mobilizes ordinary marginalized social sectors into publicly visible and contentious political action, while articulating an anti-elite, nationalistic rhetoric that valorises ordinary people. Because of that, it is difficult to imagine democratic politics without populism. The domination of predominantly anti-populist logic - consciously or unconsciously, intentionally or unintentionally - may reduce politics to an administrative enterprise with over proportionate input from colleges of experts and technocrats (depoliticised democracy, post-democracy) (Stavrakakis, 2014). The key component of populism rests with the claim to represent or act in the name of the people understood as the "common people" or the "silent majority". When minority rights are in conflict with the majority rights, populism leads to coercion aimed at oppressing the values and interests of the minority.

The core of the populist message is the rhetoric that sets up its solidary (usually national) "people" as if existing in antagonistic relationship to some kind of anti-popular "elite", often identified as an economic or political oligarchy. Typically this elite is portrayed as having disproportionate and unjustified control over conditions affecting the rights, well being and progress of the "people" (Jensen, 2011). Growing populism is usually a reaction to a crisis of a political system, salient social change that has happened or a serious challenge that is expected. This is very much visible in one of the most recent reincarnations of populism, in the post-communist world, where building on the dissatisfaction from transition and capitalist relations, populists promote ideologies that include values of strong national identity (populist nationalism), traditionalism, religion, opposition to immigration. These values have been mixed with post-socialist sentiments of universal employment, free education and other aspects of social security. Former East-block societies undoubtedly provide fertile ground for populist rhetoric.

The relations between economic and nationalist ideologies may bring explosive outcomes, as the history taught us. The crisis of liberal market capitalism produces the type of nationalism that is based on two principles: the strong authority of the state (at the expense of pluralism and the rule of law) and racism (in various variants: antiSemitism, xenophobia or others). The associations with fascism and national-socialists are evident and were already explored by Karl Mannheim (1958). At the same time 
belonging to the "people" with some protection against the "big capitalists" is the essence of populism.

Multidimensional notions define populism in general through a combination of social, political, economic and cultural characteristics. Economic populism focuses on the economic aspects of societal structures, actions, behavior and attitudes. In the practice of public life, economic populism outsources a lot from the "pub economics" (Stammtisch) that is a simplistic and emotional discourse based on rather primitive slogans and superficial knowledge. But it has one advantage - in the eyes of populist actors - it speaks to the people and convinces them.

More advanced way of conceptualizing it, is the definition that sees economic populism as a short-sighted, opportunistic policies that aim at quickly pleasing the people (buying their support) rather than looking rationally for the best or optimal solution (Mudde, 2004). It offers often contradictory prescriptions combining benefits for the poor without taxing the better off, undermining budget balance and fueling inflation, attracting foreign capital and favoring local entrepreneurs and many other inventions outside of the orthodox economic handbook.

As a consequence economic populism is an approach to economics that emphasizes growth and income redistribution and deemphasizes risks of inflation and finance deficit, external constraints and the reaction of economic agents to aggressive non-market policies. Liking or disliking the neoliberal paradigm, the reality shows that in a long-time perspective such a mix of policies do ultimately fail. In the end they are against those whom they are supposed to be favoring or protecting (Dornbusch, Edwards, 1991).

There is a number of similarities of economic populism that appear in various settings all over the world. First, the starting point usually is the deep dissatisfaction with the economy's performance. No matter if it is negative growth rates or positive but unsatisfactory one, very often associated with external pressures (IMF, migrants, etc.). Additionally unequal income distribution, real or imagined, is an effective boost for the economic populists' agenda. Secondly, the rejection of any previous (especially liberal) economic paradigm is validated. Defenders of the ancient regime are ignored, or criticized, or attacked - depending on the level of radicalism. Any constraints, internal as well as external, are treated as barriers to be demolished by the carriers of the popular legitimacy. In the third phase, when diagnosis is over, economic populist program is prescribed. It usually consists of three elements: reactivation, redistribution and restructuring. Very often they come together and are interlined - reactivation by redistribution change or revitalization of the economy by restructuring the previous economic order. The brutally simple way of correcting income redistribution is the real wage or other financial benefits increases. Even if they cause inflationary side-effects, populist policymakers will find a scape-goat, easily acceptable by the people. In many locations, like for example in Latin America, these prescriptions repeatedly ended in pervasive shortages, extreme acceleration of inflation and foreign exchange gap (Dornbusch, Edwards, 1991).

Despite of the fact that already the XIX century populism had the economic arguments at its very core, most scholars (e.g. Mudde, 2001) agree it is Latin America (1920s), where we should look for the springing of economic populism. It has to do with the specific way of defining populism in the Latin American context focusing on ad hoc 
reformist policies and looking for a "third way" between socialism and capitalism. It was predominantly correlated with what we would call today a left-wing populism, that is: interventionist role of the state, expanding welfare provisions and redistributing the wealth to the poor. ${ }^{3}$

Economic populism, just like populism in general, can be right wing as well as left wing phenomenon. Understanding it exclusively as a class conflict between the labor and the liberal elites would mean oversimplification. Right-wing economic populism seeks to restrict state intervention in the economy, privilege the national over foreign capital. In this formulation "the core people" will be the entrepreneurs, the hard-working locals. "The other" will be those whose ideas intend to undermine the healthy liberal economic system. Sometimes it can be referred to as a liberal populism, however one needs to remember various ways of understanding the very notion of liberalism. In USA liberal means roughly something like in Europe "social democratic", therefore liberal populism lies in opposition to the more right-wing populism associated with the conservative camp. Whereas in Europe liberal populism refers rather to the claims built on the neoliberal dogma. Left-wing economic populism (sometimes referred to as "social populism") will attack the liberal order ${ }^{4}$ from the egalitarian positions. Here "the people" will be the hard working labor or farmers, at the same time deprived "The others" will be the enemies of the welfare state. They will be portrayed as a cosmopolitan elite conspiring against the interests of the "real people" (robin-hooding).

Economic populism is usually legitimized by a certain reading of "Keynesianism" that gives strong (and sometimes exclusive) emphasis on the effective demand. Its extreme version is the attempt to argue for wage increases in order to promote consumption and stimulate demand. It is important to recall that Keynes has never directly recommended government deficits as a tool of economic policy. Optionally he considered them as temporary measures and when doing so he showed preference for investment over consumption spending. But economic populists ignore the fact that Keynesian analysis is useful only for short periods - they rather conceive fiscal policy as a key tool in growth strategies. As a consequence, an emerging literature has focused on the lasting problem of excessive budgetary deficits as a result of populist macroeconomic policy making. This particular approach to economics has been characterized by overly expansionist policies focusing on growth and income distribution, with little concern about such risks as inflation, budget deficits (or even deficit-debt spiral) and external constraints (Pereira, Dall'Acqua, 1991; Nicholson, 2012).

Populism is not just anti-elitist, it is anti-pluralists - and here lies its profoundly undemocratic and illiberal character (Mueller, 2015). Populist actors promise protection against the insecurities of pluralism. The "united people" rhetoric offers some kind of harmony of interest. It goes hand in hand with the overestimation, idealization and romanticizing of one's own nation and is accompanied with stereotyping and stigmatizing enemies of the nation - other nations, international organizations, capitalists, or minori-

${ }^{3}$ In late 1980s the term "neopopulism" made its debut, focusing on Latin America where neoliberal politicians, implementing austerity measures, continued to mobilize surprising levels of popular support while formulating rhetoric and pursuing policies reminiscent of a more classic Latin American populism (Jansen, 2011).

${ }^{4}$ Anti-TINA logic (TINA - There Is No Alternative) - oriented against cosmopolitan liberalism. 
ties. Populist politicians are exploiting persistent patterns of prejudice. The regular problems of everyday life are supposedly related to the presence of foreigners or minorities or other forms of aliens. Economic populism may be to a large extend explained on the basis of latent insecurity developing as a result of the democratic rules of institutionalized conflict, struggle of interest and power shifts (Keane, 1994; Weiss, 2003). The transformation from non-democracy to democracy, and from non-capitalism to capitalism is a particularly fragile period in which the enthusiasm for democracy building may dry-out very soon in the face of the social and economic unrest. Populist, nationalistic and authoritarian attitudes can be interpreted as a sentiment reaction to the "shock of modernization".

Especially in locations, where the changes took a rapid pace, for example in Central and Eastern Europe after 1989, the populist movements take advantage of the tensions between supporters of capitalism and the socialist sentiment. The sentiment is built on the imagined picture of the past emphasising social justice, equality, security and welfare. At the same time the capitalist reality is far from what was imagined at the times of transition. Instead of wide-spread prosperity and economic effectiveness, it is very often associated with instability, unemployment and insecurity. Due to the Marxist-Lenninist legacy - an economic system promoting equality - there is a significant potential for economic populism in the whole post-soviet. East Europeans, many of whom were educated and socialized under communism, are accustomed to welfare provisions typically promised by the populist politicians. This makes former East block societies particularly prone to economic and political populism (Mudde, 2001). Important to notice, some of the communist policies - at least in theory - entailed some important overlap with economic populist policies. There is no alternative and recognized strand of economic populist theory or ideology (Karl Marx, egalitarianism, etc.) and it is not a coincidence that (left-wing) economic populism overlaps to a large extend with the socialist program which went bankrupt in any real setting when implemented. Communists and today's economic populists use a very similar vocabulary and a series of shifting arguments and concepts most often referring to economic redistribution, socio-economic control and the interventionist state. As a reaction to the failure of the socialist way of organizing the economy, the neoliberal paradigm became valid. Many aspects of it were essentially populist, for example the rejection of the so far nomenklatura and the utter belief in the vitality of the people who can take the initiative to build the new economic system. Together with the increasingly unpopular neoliberal dogma, market reforms found themselves on the target. Part of this criticism was justified and rationally argumented whereas part of it based on populist re-sentiments towards the previous system. Hidden unemployment and underemployment (in the face of massive higher education promotion), wide-spread inequalities, large proportions of the society left marginalized, practically beyond the civilizational catch-up race. Market failures, oligarchisation, social unrest connected with shock therapy, he transformation fatigue and its consequences, all these facts and phenomena create a fertile breeding ground for economic populism.

There are also many niche-type of populism definitions in the economic context. One of the very representative ones is petro-populism which stands for the excessive use of oil revenues to buy political support (Natvik, Torvik, 2016). This stands very distant 
from the core definitions of populism as such an shows how flexible the term is in its usage. The gains from natural resources help the politicians to remain in office over time does not necessarily imply populist politics. It may do so in case of framing the discourse into "our people resources" vs. "the others" who may want to take advantage of it, especially at "our" cost. The very deliberations over political rent-seeking and exploitation of natural resources are quite interesting not only in Norwegian context but may be so also in the case of Russia, Venezuela and other locations. Wherever politicians reward the voters with policies that cannot be afforded (and make them used to them) in a long-time perspective and cause excessive resource extraction.

The above-stated way of conceptualising economic populism correlates very closely with the classical electoral way of understanding it. In this meaning, economic populism is present in the initiatives launched immediately prior to elections which allow a political party or a politician to retain or assume power. The populist promises employed to generate short-term gains include subsidies (or subsidy announcements), preferential loan conditions, softening of interest rates policy (to help reduce loan pay-outs), price manipulations (where possible), etc. (Srinivasan, 2014). Populist actors ignore the long-term consequences in favour of short-term electoral benefits for themselves or their parties.

And the last, but not least, type of economic populism present in today's Europe is related to Euroscepticism. Not all Eurosceptics are populists, however the scale and intensity of populist argumentation among those actors who oppose Brussels is unprecedented. Started in the post-Maastricht period, and amplified by latter developments, including the economic recession, migration crisis, lack of solidarity, Brexit crisis, and many other problems cumulating, the anti-EU populism blossomed in the second decade of the XXI century. The intergovernmental bargaining, as a politics behind the closed doors method of decision taking, oriented at resolving the above mentioned problems additionally worsened the image of Brussels. And it gave fuel to the Eurosceptic populist discourse. In the context of the European integration process, it has become fashionable (at least in 1990s.) to point to the emergence of populism, with or without a nationalist component. Populism towards Brussels was usually explained with the loss of integrative impetus in the post-Maastricht period (Hayward, 1996). Additionally the discussion on democratic deficit and the disappointment connected with the enlargement fatigue in the West, and transition fatigue (largely driven by Europeanisation mechanisms) in the East, accompanied by economic recession factors like unemployment, created a solid fundaments for the emergence of the anti-EU arguments which often took the populist form. The EU with its ambition to be a value system is at the natural conflicting trajectory with the defenders of alternative value systems, including the domestic populist politicians. EU becomes a natural enemy of the populists, especially because it is equipped with some anti-populist weapons, a toolkit to protect liberal democracy and monitor compliance with the rule of law. Within a limited range of strategies for opposition available, the EU can try to apply strong pressure on a government built by a populist party or leader threatening the standards of liberal democracy (Taggart, Kaltwasser, 2016). The $\mathrm{EU}$, as a regulatory super-power, provides a means to set a certain limits to populism, or it seemed so in the past (Rupnik, 2007). By doing this, it becomes the natural enemy of the populists. 


\section{Conclusions}

Both nationalism and populism have a very strong economic dimension. First defined as one of the grand ideologies of our times, the second just a thin-centered ideology, both capturing the economic argumentation and persuasion. They also both exploit the similar political cleavages: winners and losers of the modernisation process, political centre and peripheries, gender divines, locals vs. aliens, Brussels vs. the rest, etc. And they are both successful enough that they have made it into the mainstream of politics. Politicians cannot afford anymore not to apply populist rhetoric. Moreover, it is the citizens who have been accepting more and more the populist discourse. In the end it is political and economic scientists who have become more tolerant towards populism in their critical analysis. The same happens with economic nationalism, no matter if in its left-wing or right-wing form, there is much more tolerance for it both in electoral politics and the intellectual debates.

Various disciplines suggest various explanations as regards the determinants of the nationalists' and populists' success. Socio-psychological factors include authoritarian personality traits and value orientations which are, in turn, associated with social disintegration coexistent with the times of radical change (like transformation, crisis, etc.). Isaiah Berlin claimed that populism could maintain only in societies standing at the edge of modernisation (Berlin, 1968). This way of thinking correlates with modernisation theory in which it is suggested that the rapid socio-economic change (post-communism, postindustrialisation, risk-society, etc.) makes individuals and groups aggressive and hostile. Rational choice logic points to the mechanism of scapegoating and group interest conflicts, suggesting that prejudice, discrimination and sometimes outright conflict is a natural result of competition over limited resources. Identity studies focus on perceived threats posed by migrants on the nation and its culture. Socio-structural models explain support for the populist far right by the aggregate level of immigration in a given country or locality (its height and the increasing trend), economic conditions (unemployment, wage levels) and the level of support for the political system (political discontent). Last but not least, it is the media that play a decisive role in formulating, especially young people's attitudes towards migrant and migration. Young people's support for nationalist and far right ideology consists of negative attitudes towards minorities, xenophobia, welfare chauvinism and exclusionism in relation to migrants. Ethnic nationalism, financial problems and economic insecurity (perceived competition and pressure on socio-economic resources) belong to the most important factors behind the relatively high prevalence of anti-migrant sentiments in CEE. Additionally the scholarly research results show that low interest and poor understanding of politics, together with high exposure to media (which, instead of educating and dispelling prejudice, further worsen attitudes towards minorities and migrants) go hand in hand with accepting far right populist message (Mielina, Karoleva, 2015).

Populists and nationalists usually offer a dichotomous vision of society and socioeconomic relations. They both share an idea of political antagonists as enemies who are potentially traitors to the nation or the people. Populists and nationalists identify themselves with the very heartland of the imagined political community which they want to serve. They both use tabloid-style communication - simplified, emotional, distrusting the others, dissatisfaction-grounded. Populism grows very fast on the fertile ground of political discontent. At the same time populists, once strong, fuel the political discontent 
(Rooduijn, van der Brug, de Lange, 2016). It makes populism both the source and the consequence of political discontent. This mechanism creates a vicious circle of populism and nationalism on one side and the political discontent on the other.

\section{Bibliography}

Aslanidis P. (2015), Is Populism an Ideology? A Refutation and a New Perspective, "Political Studies", pp. 1-17.

Baughn C. C., Yaprak A. (1996), Economic Nationalism: Conceptual and Empirical Development, "Political Psychology", no. 17 (4), pp. 759-778.

Berend I. (2000), The Failure of Economic Nationalism. Central and Eastern Europe Before World War II, "Revue economique", no. 51 (2), pp. 315-322.

Berlin I. (1968), To Define Populism, "Government and Opposition”, no. 3 (2), pp. 137-197.

Black D. J. (1928), The McNary-Haugen Movement, "The American Economic Review", no. 3, vol. XVIII, pp. 405-427.

Dornbusch R., Edwards S. (1991), The Macroeconomics of Populism in Latin America, Chicago.

Freeden M. (1998), Is Nationalism a Distinct Ideology?, "Political Studies”, no. 46 (4), pp. 748-765.

Gilpin R. (1987), The Political Economy of International Relations, Princeton.

Helleiner E. (2002), Economic Nationalism as a Challenge to Economic Liberalism. Lessons from the $19^{\text {th }}$ Century, "International Studies Quarterly", no. 46, pp. 307-329.

Wendy I.-M. (2011), National Identity and Economic Nationalism. Can an Economic Perspective Reinforce Nationalism and Nation Building?, "Africa Insight", no. 41 (1), pp. 59-70.

Jansen S. R. (2011), Populist Mobilisation: A New Theoretical Approach to Populism, "Sociological Theory", no. 29 (2), pp. 75-96.

Keane J. (1994), Nations, nationalism and citizens in Europe, "International Social Science Journal", no. 4, pp. 169-184.

Kluknavska A. (2014), Enemies among us: The anti-elitist and xenophobic discourses in the Czech Republic and Slovakia, "Rexter - casopis pro vyzkum radikalismu, extremismu a terrorismu", no. 2, pp. 42-71.

Kubik J. (2012), Illiberal Change to Liberal Democracy. The Case of Poland, "Taiwan Journal of Democracy", no. 8 (2), pp. 79-89.

List F. (1904) The National System of Political Economy, translated by S. Lloyd, London.

Mielina I., Koroleva I. (2015), Supporters for far right ideology and anti-migrant attitudes among youth in Europe: A comparative analysis, "The Sociological Review", no. 63 (2), pp. 183-205.

Moffit B., Tormey S. (2014) Rethinking Populism: Politics, Mediatisation and Political Style, "Political Studies", no. 62, pp. 381-397.

Mudde C. (2001), In the Name of the Peasantry, the Proletariat and the People: Populism in Eastern Europe, "East European Politics and Societies" March, p. 33-53.

Mudde C. (2004), The Populist Zeitgeist, "Government and Opposition, no. 39 (4), pp. 542-543.

Mudde C., Kaltwasser C. (eds.) (2012), Populism in Europe and the Americas, Threat or Corrective for Democracy, Cambridge University Press.

Mueller J.-W. (2015), Parsing populism. Who is and who is not a populist these days?, "Juncture", no. 22 (2), pp. 80-89.

Nakano T. (2004), Theorising economic nationalism, "Nations and Nationalism", no. 10 (3), pp. 211-229.

Natvik G., Torvik R. (2016), Petro-Populism, "Journal of Development Economics”, no. 118, pp. 1-12.

Nicholson P. S. (2012), Who's the Party of the People? Economic Populism and the U.S. Public's Beliefs About Political Parties, "Political Behaviour", no. 34, pp. 369-389. 
Pereira B. L., Dall'Acqua F. (1991), Economic populism versus Keynes: reinterpreting budget deficit in Latin America, "Journal of Post Keynesian Economics", no. 14 (1), pp. 29-38.

Pryke S. (2012), Economic Nationalism: Theory, History and Prospects, "Global policy", no. 3 (3), pp. 281-291.

Rooduijn M., van der Burg W., de Lange S. (2016), Expressing or fuelling discontent? The relationship between populist voting and political discontent, "Electoral Studies", no. 43, pp. 32-40.

Rupnik J. (2007), From Democracy Fatigue to Populist Backslash, “Journal of Democracy”, no. 18 (4), pp. $17-25$.

Shulman S. (2000), Nationalist Sources of International Economic Integration, "International Studies Quarterly", no. 44, pp. 365-390.

Srinivasan S. (2014), Economic populism, partial deregulation of transport fuels and electoral outcomes in India, "Energy Policy", no. 68, pp. 465-475.

Stavrakakis Y. (2014), The Return of the "People": Populism and Anti-Populism in he Shadow of the Europea Crisis.

Taggart P. (2004), Populism and representative politics in contemporary Europe, "Journal of Political Ideologies", no. 9 (3).

Taggart P., Kaltwasser R. C. (2016), Dealing with populists in government: some comparative conclusions, "Democratisation", no. 23 (2), pp. 345-365.

Weiss H. (2003), A Cross-National Comparison of Nationalism in Austria, the Czech and Slovac Republics, Hungary and Poland, "Political Psychology", no. 24 (2), pp. 377-401.

Wills J. (2015), Populism, localism and the geography of democracy, “Geoforum”, no. 62, pp. 188-189.

\section{Ekonomiczny nacjonalizm i populizm - przenikające się relacje}

\section{Streszczenie}

Celem niniejszego artykułu jest zaprezentowanie analizy dwóch, bardzo ściśle powiązanych ze sobą kategorii, nacjonalizmu ekonomicznego oraz ekonomicznego populizmu. Obie kategorie przenikają się zarówno w realnej polityce, jak i w refleksji akademickiej. Mimo bardzo bogatego dyskursu naukowego na temat obydwu, ich badacze cały czas spierają się nie tylko na temat tego jak je wyjaśniać, ale nawet co do ich zasadniczych treści. Zaproponowana analiza stanowi odpowiedź na ten deficyt i próbuje skupić się na związkach ekonomicznego populizmu i nacjonalizmu. W pierwszej kolejności dokonana została rekonstrukcja podstawowych sposobów rozumienia nacjonalizmu ekonomicznego - jego elementów konstytutywnych, jego historyczności, periodyzacji, jak również podstawowych kategoryzacji. Następna część koncentruje swoją uwagę na populizmie, eksponując jednocześnie jego wymiar ekonomiczny. W części konkludywnej, podobnie jak w całym tekście, autor uwypukla zachodzące relacje pomiędzy nacjonalizmem i populizmem ekonomicznym, ich wzajemnie nachodzące na siebie elementy oraz elementy rozbieżne. Początki populizmu (jako ruchu) były z natury ekonomiczne. Populizm ekonomiczny (jako swego rodzaju "pusta" ideologia) przenika nacjonalizm, kreując wiele z jego współczesnych (re)inkarnacji. Zarówno ekonomiczny populizm, jak i nacjonalizm gospodarczy stają się coraz bardziej istotnymi kategoriami analitycznymi, w związku z rosnącym znaczeniem sił nacjonalistycznych i populistycznych, i z tego powodu wymagają zaawansowanej refleksji naukowej.

Słowa kluczowe: ekonomiczny nacjonalizm, populizm ekonomiczny, treści, relacje 